\title{
THE UKRAINIAN THEME IN THE SPANISH LANGUAGE LITERARY STUDIES OF THE DIASPORA
}

\author{
Pronkevich Oleksandr \\ Doctor of Philology, Professor \\ ORCID ID 0000-0003-4354-3294 \\ Petro Mohyla Black Sea National University \\ 68, Desantnykiv St, Mykolaiv, 54000, Ukraine \\ oleksandrpronkevych@yahoo.com
}

The paper recounts about the first and still the only attempt to present Ukrainian literature in the Spanish language which was undertaken by Dmytro Buchynskyi, Petro Kluk, Dmytro Chyzhevskyi, and Yuriy Shevelov. They tell their Spanish readers about the key phenomena and names of Ukrainian literature and interpret the latter as reflection of the Ukrainian identity produced by combination of national spirit and European values. $D$. Buchynskyi and P. Kluk, who lived in Spain and wrote Spanish, focused on analysis of Spanish imagery in the works of Ivan Franko, Lesia Ukrainka, Spyrydon Cherkasenko, and Natalena Koroleva. The hermeneutics of D. Chyzhevskyi and Y. Shevelov, whose essays were translated into Spanish for the special issue of the journal Oriente Europeo dedicated to Ukraine (1957), reflect a broader European perspective. All Ukrainian emigrant intellectuals, whose essays are studied in the paper, reject models of understanding Ukrainian literature which were imposed by the official Soviet literary studies. D. Buchynskyi and P. Kluk embody this trend by emphasizing religious and humanistic values in the works of Ivan Franko and Lesia Ukrainka. D. Chyzhevskyi argues that the baroque Ukrainian literature, which was prohibited in the USSR, was a mediator in exchange of ideas, including theology, between West and East. Y. Shevelov plays a special role in undermining the Soviet version of the Ukrainian literary canon of the first half of the $20^{\text {th }}$ century. He declares the Soviet regime a mortal threat to literary imagination. The researcher restores the list of writers deleted from the Ukrainian cultural memory by the Stalinist terror and provides examples of original reading of the works of Pavlo Tychyna, Mykhail Semenko, Mykola Kvyliovyi, Mykola Kulish and others. The essays about Ukrainian literature published in Spain is a dramatic episode of the cultural war of the Ukrainian diaspora against the Soviet version of the Ukrainian literary canon.

Key words: Ukrainian diaspora in Spain, Spanish theme in Ukrainian literature, literary hermeneutics, canon, ideology, Cold War.

\section{УКРАЇНСЬКА ТЕМАТИКА В ІСПАНСЬКОМУ ЛІТЕРАТУРОЗНАВЧОМУ ДИСКУРСІ ДІАСПОРИ}

\author{
Пронкевич Олександр \\ Доктор філологічних наук, професор \\ ORCID ID 0000-0003-4354-3294 \\ Чорноморський національний університет імені Петра Могили \\ вул. 68 Десантників, Миколаїв, 54000, Миколаїв, Україна \\ oleksandrpronkevych@yahoo.com
}

У статті йдеться про першу й поки щзо єдину іспаномовну спробу представлення історії української літератури, яка була здійснена Дмитром Бучинським, Петром Клюком, Дмитром Чижевським і Юрієм Шевельовим. Вони знайомлять іспаномовну спільноту з ключовими явищами та іменами української літератури, а також

(C) Pronkevich O., 2020 
пропонують прочитання останньої як відображення української ідентичності, щзо $\epsilon$ феноменом начіональним $i$, водночас, європейським. Д. Бучинський $і$ П. Клюк, які жсили в Іспанії й писали іспанською мовою, зосередилися на аналізі іспанської тематики у творах Івана Франка, Лесі Украйнки, Спиридона Черкасенка й Наталени Королеви. Підходи Д. Чижевського та Ю. Шевельова, чиї розвідки були перекладені іспанською мовою для спеціального випуску журналу «Свропейський Схід», присвяченого Україні (1957 р.), вирізняються широким європеїзмом. Усі згадані науковиі заперечують підходи до потрактування украӥнської літератури, нав'язані офіиійним радянським літературознавством. У Д. Бучинського й П. Клюка ия тенденція проявляється у підкресленні в доробку Івана Франка й Лесі Українки релігійної та загальнолюдської проблематики. Д. Чижевський стверджує, щзо украӥнська література за часів бароко, забороненого в СРСР, виконувала роль посередника в обміні ідей, у тому числі релігійних, між Заходом і Сходом. Окрема роль у «розрадяненні» украӥнського літературного канону першої половини ХХ ст. належить Юрію Шевельову, який оголошує радянський світогляд смертельною загрозою літературній уяві. Він відновлює список ключових репрезентантів українського літературного канону, викреслених із культурної пам'яті внаслідок сталінських репресій, $i$ подає приклади вільної від більшовицьких штампів інтерпретаиії творчості окремих найважливіших письменників, таких як Павло Тичина, Михайль Семенко, Микола Хвильовий, Микола Куліш та ін. Розвідки з української літератури, надруковані в Іспанії, є яскравим епізодом культурної війни з радянським літературним каноном, яку вела й веде украӥнська діаспора.

Ключові слова: українська діаспора в Іспанії, іспанська тематика в українській літературі, літературна герменевтика, канон, ідеологія, Холодна війна.

\section{Вступ}

Українські емігранти різних поколінь завжди витрачали колосальні зусилля на конструювання позитивного образу своєї Батьківщини на Заході, і не останню роль у цих практиках відіграють праці, присвячені вивченню історії української літератури. Існує чимало робіт англійською мовою 3 цього питання ${ }^{1}$, чого не можна сказати про світ іспаномовний, хоча присутність у ньому українців була й залишається значною. У цій розвідці йдеться про першу й поки що єдину іспаномовну спробу представити вільну від радянських кліше історію української літератури, про яку навіть вузькі спеціалісти досі нічого не знають. Зокрема, йдеться про іспаномовний

\footnotetext{
${ }^{1}$ Andrusyshen C. H. Ukrainian literature and its guiding light Shevchenko / Constantine Henry Andrusyshen. - Winnipeg : Ukrainian National Youth Federation of Canada, 1949. 32 p.; Grabowicz G. Toward a History of Ukrainian Literature (Harvard Series in Ukrainian Studies) / George Grabowicz. - Cambridge : Harvard Ukrainian Research Institute, 1981. 112 p.; Luckyj G. S. N. Literary politics in the Soviet Ukraine, 1917-1934/ George S. N. Luckyj. - Durham : Duke University Press Books, 1990. - 367 p.; Luckyj G. S. N. Ukrainian Literature in the Twentieth century. Readers Guide / George S. N. Luckyj. Toronto : University of Toronto, 1992. - 136 p.; Shtohryn D., Rozumnyi J. Twentieth century Ukrainian literature : essays in honor of Dmytro Shtohryn / Dmytro Shtohryn, Jaroslav Rozumnyi. - Kyiv : Kyiv Mohyla Academy Publishing House, 2011. - 367 p.; Tschižewskij D. A history of Ukrainian literature: from the 11th to the end of the 19th century / Dmitrij Tschižewskij. - Littleton, Colo : Ukrainian Academic Press, 1975. 327 p.; Tschizewskij D., Luckyj G. S. N. A History of Ukrainian Literature (From the 11th to the End of the 19th Century): With an Overview of the Twentieth Century / Dmitrij Tschižewskij, George S. N. Luckyj. - Englewood, CO : Ukranian Academic Pr, 1997. 815 p.; Yatchew J. Ukrainian literature, prefaced by an outline of Ukrainian History / John Yatchew. - Edmonton : University of Alberta, 1924. - 297 p.
} 
літературознавчий доробок Дмитра Бучинського, який з 1950 по 1962 рік проживав у Мадриді, захищену 1971 року в Університеті Комплутенсе дисертацію Петра Клюка, представника першої хвилі української еміграції в Іспанії, а також перекладені іспанською мовою статті Дмитра Чижевського та Юрія Шевельова, які були надруковані у спеціальному присвяченому Україні числі журналу «Свропейський Схід» (1957 р.).

Перш ніж перейти до безпосереднього вивчення вищезгаданих наукових праць, варто зробити одне вступне зауваження, яке характеризує роль і місце літературознавчих досліджень в ідеологічній та естетичній програмі української діаспори загалом. Стислий виклад цієї програми міститься ще в праці О. Ряста (псевдонім Симона Петлюри) з показовою назвою «Сучасна українська еміграція та їі завдання» (1921р.). Автор брошури закликає кожного українця, що виїхав за кордон з СРСР, дивитися на себе як на політичного емігранта й посла власної культури, який, незалежно від професійної приналежності, повинен сприяти поширенню правдивої інформації про Україну в кожній країні, до якої він потрапив [6, с. 30-71]. Від власне філологів (мовознавців, літературознавців, перекладачів тощо) ця програма вимагає обов'язкового включення в коло своїх наукових досліджень і творчих програм україноцентричної проблематики. Легко зрозуміти в цьому контексті ту роль, яка відводиться дослідженням з української літератури, адже саме iii засобами відбувається формування широкого кола національних цінностей та ідеалів. У той же час видані іноземними мовами літературні твори й наукові розвідки про них слугують візитівками України.

Окреслені складові «культурного кодексу поведінки українського емігранта» повторює заключна стаття «Українська еміграція у вільному світі» Ярослава Стельмахіва, відповідального редактора спеціального випуску журналу «Свропейський Схід» [18, с. 243-250]. Щоправда, в реаліях 1950-х рр. ця програма набуває специфічних рис, оскільки інтегрується в глобальне протистояння між Заходом і Сходом, між світами капіталізму й комунізму, спричинене Холодною війною. Українські літературознавці, що друкували свої розвідки в Іспанії протягом 1950-х pp., були на західному боці. Їхні політичні погляди були різними, але солідаризувалися вони в одному - у своєму послідовному неприйнятті культурних моделей української національної ідентичності й, зокрема, принципів структурування історії української літератури, що нав'язувалися СРСР. У результаті літературознавчі конвенції, якими вони послуговувались, відображають альтернативне радянському розуміння української ідентичності як явища глибоко національного й водночас європейського.

\section{Дмитро Бучинський}

Дмитро Григорович Бучинський (1913-1963) без перебільшення був справжнім першовідкривачем української літератури в іспаномовному світі. Біографічні дані про нього можна знайти в «Енциклопедії сучасної України» [4] та в «Енциклопедії Наукового товариства ім. Шевченка» [7]. Є інформація про нього і в українській Вікіпедії. Д. Бучинський є автором історико-літературних праць про Юрія Клена [3] й Тараса Шевченка [2]. Немає сенсу повторювати всі відомі факти, що становлять його життєвий шлях, але варто підкреслити ті аспекти його багатогранної діяльності, які сприяли поширенню знання про українську літературу в Іспанії. Він переклав іспанською мовою «Слово о полку Ігоревім», організовував виставки книг у Національній бібліотеці Іспанії, регулярно звертався до літературознавчої та культурознавчої проблематики у своїх журналістських публікаціях. Д. Бучинський виступав із доповідями перед українськими студентами-емігрантами, які навчались у Мадриді. Зокрема, він говорив про такі теми, як «філософія Сковороди, культ Діви Марії в Україні, життя і твори Наталени Королеви, Тарас Шевченко, Іван Франко» [8, с. 78], які відображали коло його наукових зацікавлень і відбились у його власних 
літературознавчих розвідках, а також у наукових працях Петра Клюка, одного з тих, хто був присутній на цих зустрічах.

Говорячи про іспаномовний доробок Д. Бучинського, варто зупинитися на його статті «Іван Франко й іспанська література» («Iván Frankó y literatura española)», надрукованій у першому числі журналу «La revista de literatura» («Літературний журнал») за 1953 рік. На цю роботу постійно посилаються науковці, що вивчають рецепцію Сервантеса й Кальдерона в Україні, але сама літературознавча герменевтика, якою послуговувався Д. Бучинський, зокрема, ідеологічно-естетичні засади, з яких розглядається феномен Івана Франка, ще досі не ставали предметом аналізу.

Завдання розвідки Д. Бучинського - запропонувати альтернативне радянському прочитання життя і творчості українського класика: Іван Франко постає не як революціонер-інтернаціоналіст, а як репрезентант національної української та європейської духовності. Це символ європейської України. «Він є справжнім сином нашого народу, без навіть найменшої тіні фальшивого патріотизму, який для своїх людей бажав лише свободи, що не порушує права вільної людини інших націй» [9, c. 56]. В інтелектуальному портреті I. Франка, змальованому Д. Бучинським, превалюють риси європейського гуманіста ренесансного типу: «Письменник був людиною, яка прагнула охопити інтереси людства» [9, с. 57]. Його гасла - «праця, щастя і свобода» $[9$, с. 58].

Д. Бучинський звертає увагу на той факт, що Іван Франко був першим, хто відкрив українському читачеві багатьох класиків світової літератури й деяких найвидатніших письменників Іспанії та використав іспанські мотиви для своїх творів, зокрема, в поезії «Конкістадори». Він зробив переказ «Дон Кіхота» й підготував для української сцени «Саламейського алькальда» Кальдерона [9, с. 69]. Поему I. Франка «Пригоди Дон Кіхота» дослідник визначає як «переробку (transformación) роману у віршах, яка розповідає про пригоди Дон Кіхота в гумористичному тоні, але без надмірної карикатурності; Дон Кіхот Франка - це герой і лицар, який бореться за тріумф правди на землі» [9, с. 70]. Коментуючи образ Педро Креспо, Д. Бучинський підкреслює, що І. Франко переписав «Саламейського алькальда», тому що «у творі Кальдерона $\epsilon$ один чудовий тип селянина, для якого правда і справедливість $\epsilon$ не тільки метою життя, а й самим життям. Поет зосередив свою увагу на високій моралі твору Кальдерона, в результаті створив переробку, аби підкреслити ідею, що українець повинен наслідувати моральну силу (іспанського персонажа - O.B.) й навчитися у нього захищати свої права, свою честь, незважаючи на статус того, хто його ображає: ідальго, військовий або навіть сам король» [9, с. 74].

Д. Бучинський завершує свою розвідку описом спільних рис українців та іспанців: i ті, й інші «протягом багатьох століть боролися за ті самі ідеали, за свободу, справедливість і свободу духу» [9, с. 77]. За логікою Д. Бучинського, Іван Франко за допомогою своїх «перекладів» іспанської класики змальовує образ України як європейської країни. Принаймні він вказує на Європу, зокрема на Іспанію, як на позитивний приклад, якому українці мають слідувати.

Важливо підкреслити, що подібною логікою Д. Бучинський керується й вибираючи поезії Івана Франка для друку у власному перекладі в 56 числі журналу «Іспанська поезія» («Poesía española») за 1956 рік [12, с. 26-28]. Увагу українського інтелектуала привернула поезія «Христос i Хрест», написана цілком у дусі іспанських містиків, і згаданий вище вірш «Конкістадори», який оспівує завоювання Америки Ернаном Кортесом. У пролозі Д. Бучинський повторює свою характеристику Івана Франка як квінтесенції національно свідомого українства, що водночас $\epsilon$ репрезентантом відкритого типу свідомості та європейських гуманістичних цінностей: «Франко є братом усіх людей, незважаючи на національні або державні кордони. Він вірить у людство, і тому проголошує: “Той, хто має чисте серце і чесну думку, вільну свідомість, щирість відчуття, і у чиїх грудях палає 
сміливість, - той повинен стати на великий бій за добро, за свободу й за щастя всіх"» $[10$, c. 26$]$.

\section{Петро Клюк}

Ще одним джерелом знань про українську літературу в Іспанії 1950-х рр. була група студентів-емігрантів, які вчилися у Мадриді в Центральному університеті (зараз Університет Комплутенсе) і в деяких інших університетах іспанської столиці. Докладну інформацію про цей епізод в історії української діаспори можна знайти у книзі спогадів Володимира Яримовича, Олександра Білика та Миколи Волинського «Нарис історії Української Студентської Громади та Українських Поселень в Еспанії 1946-1996», яка була видана 1997 року у Філадельфії та Мадриді [8]. Цей документ уже був проаналізований автором цієї розвідки [16], тому в подальшому викладі має сенс повторити тільки деякі найважливіші факти, дотичні до історико-літературної проблематики.

Група українських студентів формувалася 3 військовополонених із дивізії СС «Галичина», що за рахунок стипендії від організації «Рах Romana», підтримуваної Ватиканом, з 1946 по 1962 рік навчалися в іспанській столиці на різних факультетах і створили власну організацію «Обнова», підпорядковану керівному центру у Федеративній Республіці Німеччина. За своїми поглядами вони були правими націоналістами, близькими до франкізму, офіційної ідеології Іспанії тих часів. Українська громада була невеличкою, але добре згуртованою. Автори спогадів повідомляють, що понад 70 українських студентів навчалися в Мадриді, 3 них 90 відсотків отримали дипломи [8, с. 189]. Після завершення навчання більшість із них переїхали до США, Канади, Аргентини, Австралії, в результаті чого «Обнова» припинила своє існування.

Члени української студентської громади зробили помітний внесок у розповсюдження української культури в Іспанії. Вони створили хор, який брав участь у літургіях і виконував українські народні пісні, відзначали національні свята, підтримували дружні стосунки 3 ієрархами іспанської католицької церкви, відвідували культурні заходи, організовані Дмитром Бучинським, іншими інтелектуалами діаспори, які або жили в Мадриді, або відвідували місто, - такими як Леонід Полтава, Володимир Пастушук та ін. Вони співпрацювали з українською редакцією Іспанського національного радіо, яке з 1951 по 1973 р. транслювало передачі українською мовою на СРСР. Хоча серед членів громади було лише декілька професійних філологів, українські студенти в Мадриді ніколи не забували про українську літературу, яку, щоправда, тлумачили у специфічному ідеологічному вимірі. Прикладом цього може слугувати коментар відомої поезії Богдана-Ігоря Антонича «Пісня про Альказар», переклад якої був виконаний Д. Бучинським і подарований Меморіалу захисників Алькасара в Толедо в 1956 р. під час приїзду до Іспанії відомого українського лінгвіста Ярослава Рудницького, який проживав у Канаді. В. Яримович, О. Білик і М. Волинський таким словами коментують цю подію: «Захоплений відвагою і чинами оборонців Альказару, наш поет Б. І. Антонич написав тоді у Львові свій вірш "Слово про Альказар" і присвятив його хоробрим героям тих подій. Копію цього вірша привіз із собою до Еспанії проф. Я. Рудницький, шкільний товариш i приятель із студентських часів поета Б. Антонича. Завдяки заходам д-ра Д. Бучинського було зроблено гарно виконані тексти українського оригіналу та еспанського перекладу цього вірша, оправленого в рамки i, після отримання дозволу в генерала Москарда, поміщено на одному 3 кращих місць Альказару, яке легко побачити від входу» [8, с. 141]. Процитований текст не залишає сумніву з приводу того, що українські емігранти першої хвилі інтерпретували цю складну й суперечливу поезію Б.-І. Антонича цілком суголосно франкістській ідеології: як оспівування величі й трагедії, а також лицарського духу 
Громадянської війни в Іспанії 1936-1939 рр., що найяскравіше проявився під час облоги Алькасара в Толедо.

Одна постать серед представників української студентської громади заслуговує в цій розвідці на окрему увагу. Це Петро Клюк (1922 року народження) $)^{1}$ [5], автор першої дисертації про українську літературу в Іспанії [14]. Вона була захищена під назвою «Іспанська тематика в українській поезії» в Мадридському університеті 1971 року під керівництвом Марія дель Пілар Паломо Васкес (María del Pilar Palomo Vázquez) [14]. Матеріал, проаналізований автором дисертації, можна поділити на три тематичні блоки: 1) образ Дон Жуана (Дон Хуана) в українській літературі, 2) іспанські мотиви й теми в Івана Франка, 3) біографічний твір «Предок» Наталени Королеви, української письменниці 3 іспанським корінням. Говорячи про перший аспект розвідки, П. Клюк вивчає текстуальні зв'язки драми Лесі Українки «Камінний господар» із філософською драмою Тірсо де Моліни «Севільський жартівник» (або «Севільський обманець» у діаспорному перекладі). Серед інших класиків іспанської, світової та української літератури, які були відомі Лесі Українці й у той чи інший спосіб могли вплинути на іiі задум, П. Клюк згадує Сервантеса, Лопе де Вегу, Сорілью, Мольєра, Гофмана, Пушкіна, П. Куліша. На думку П. Клюка, в ідейному плані твір Лесі Українки зосереджений на проблемах влади і свободи, головні персонажі п’єси є символами української дійсності, а найбільшого значення в драмі набувають ідеал жінки та політично-соціальні ідеї. Слід відзначити, що дисертація П. Клюка досі невідома українським та іноземним дослідникам «Камінного господаря», хоча в деяких своїх спостереженнях (зокрема, у відзначенні ролі жінки) науковець багато в чому випередив час. Крім Дон Жуана Лесі Українки, П. Клюк приділяє чималу увагу ще одному твору - драмі «Дон Хуан і Розіта» Спиридона Черкасенка. Друга частина дисертації $є$ розвитком ідей Д. Бучинського, який досліджував іспанську тематику в творчості Івана Франка. П. Клюк розглядає «Війта Заламейського» (переробку «Саламейського алькальда» Кальдерона), «Пригоди Дон Кіхота» й вірш «Конкістадори». Ще двома віршованими текстами I. Франка, де розробляється іспанська тематика, є романси «Добра дочка» й «Вірна жінка», в яких український поет оспівує такі цінності, художньо осмислені в іспанській літературі, як жіночі честь і вірність. У частині розвідки, присвяченій Наталені Королеві, П. Клюк повідомляє факти іï біографічного зв'язку з Іспанією, розглядає архівні матеріали, а також іспанські традиції, які дозволяють розкрити цей зв'язок в автобіографічному творі письменниці «Предок». Завершуючи огляд доробку Петра Клюка $з$ українсько-іспанської тематики, не можна не згадати його переклад драми «Камінний господар» («El dueño de piedra») Лесі Українки [15], здійснений за допомогою професора Карлоса Хіменеса.

Історія української літератури на сторінках спеціального випуску журналу «Свропейський Схід»

Журнал «Свропейський Схід» («Oriente Europeo») видавався в Мадриді між 1950 i серединою 1960-х рр. Центром східних досліджень, яким керував єзуїт Сантьяго Морільо. В цьому Центрі співпрацював Дмитро Бучинський. Сам Сантьяго Морільо викладав у 1930-ті роки в семінарії в м. Дубно й після початку Другої світової війни повернувся до Іспанії, де сфокусувався на дослідницько-пропагандистській роботі 3 країнами європейського сходу i, зокрема, Україною [13]. Він же був одним із патронів і наставників українських студентів-емігрантів [8, с. 32, с. 38]. Таким чином, усі особи, причетні до створення іспаномовної версії історії української літератури, чиї праці розглядаються в цій статті, були пов'язані між собою й становили міцне

\footnotetext{
${ }^{1}$ Фотографію Петра Клюка можна побачити на сайті Філадельфійського осередку Наукового товариства Тараса Шевченка Америки [1].
} 
ядро. Завдання журналу полягало в тому, щоб із християнських засад «висвітлити найгострішу моральну проблему сучасності - винищення людяності (la estructura humanaм) військовим та ідеологічно-політичним пригніченням, яке радянщина (sovietismo) влаштувала в половині Європи» [11, с. 102-103]. Редакція практикувала монографічні випуски, присвячені країнам, що опинилися під впливом СРСР: Польщі (№ 25), Угорщині (№ 27), Німеччині й Австрії (№ 28) та ін. 1957 року побачило світ число 26, темою якого була Україна. До співпраці були залучені ієрархи грекокатолицької церкви, а серед авторів фігурували такі відомі українські інтелектуали, як Олександр Шульгін, Лев Білас, Дмитро Андрієвський, Богдан Кордюк, Василь Маркус та ін. Журнал містив публікації про історію, етнографію, географію, церкву України. Тексти спеціально писалися для журналу, а потім перекладалися іспанською мовою. В результаті читач мав справу з надзвичайно фаховим виданням.

Авторами двох літературознавчих розвідок стали найвідоміші українські філологи XX ст. Дмитро Чижевський і Юрій Шевельов, що зайвий раз свідчить про високу наукову якість журналу. Їхній підхід до осмислення української літератури як явища національного та європейського дещо відрізняється від того, яким послуговуються Дмитро Бучинський і Петро Клюк. Якщо останні розглядають твори українських класиків крізь призму іспанської образності, то Д. Чижевський і Ю. Шевельов дивляться на українську літературу як на інтегральну частину загальноєвропейського літературного процесу.

У цьому сенсі вибір теми українського бароко виглядає цілком природним. Дмитро Чижевський у розвідці «Бароко в українській літературі» виходить із того факту, що цей період $є$ одним із найвищих досягнень української літератури. Роз'яснивши його специфічні риси, науковець стверджує, що тоді в українську культуру активно проникають теми й образи європейської античності, які використовуються для ілюстрації християнських цінностей. Дмитро Чижевський підкреслює, що Іван Вишенський, один із перших творців барокового стилю в Україні, добре знав мистецтво й літературу польського бароко, що стало основою його власного оригінального інтелектуально-художнього світу. Аналогічну тенденцію вписування європейських феноменів Д. Чижевський спостерігає в працях Мелетія Смотрицького, Кирила Транквіліона Ставровецького, Лазаря Барановича, Григорія Сковороди та багатьох інших. Крім культурного й художнього спадку, українське бароко надає нового життя західним філософсько-теологічним ідеям. Д. Чижевський переконливо доводить, що київські християнські інтелектуали XVIIXVIII століть завдяки поширенню єзуїтської моделі освіти, яка активно використовувала практики перекладу 3 грецької та латини, були достатньо ознайомлені 3 ідеями найвпливовіших європейських мислителів Відродження і бароко. «Була також відома й релігійна література, яка здійснювала вплив на літературу світську (наприклад, релігійні пісні, твори містиків та ін.)» [19, с. 88-189]. Добою бароко датуються перші серйозні спроби перекладати українською мовою трактати Плутарха, Цицерона тощо (так звані переклади-реконструкції, здійснені Григорієм Сковородою). На думку Д. Чижевського, культура українського бароко започаткувала процес європеїзації всієї Східної Європи, включаючи Московію. Доказами європейського духу українського бароко, на який вказує дослідник, є існування української школи в польській бароковій літературі, а також вплив українських письменників того часу на письменників Центральної та Південної Європи. Одне слово, Д. Чижевський представляє українське бароко як феномен глибоко національний i, водночас, цілком інтегрований в обмін ідеями між Заходом і Сходом. Багато з того, що стверджує Д. Чижевський, вже добре відоме сучасному читачеві, але варто ще раз нагадати, що йдеться про 1957 рік, коли самий концепт «українське бароко» був у СРСР під забороною, і про Іспанію, для якої саме слово «Україна» звучало як суцільна екзотика. Враховуючи ці обставини, сьогодні можна тільки дивуватися сміливості й переконливості тієї риторики, яку використовував Д. Чижевський для того, щоб піднести українську літературу на рівень європейської. 
Ще один автор Юрій Шевельов у розвідці «Тенденції української літератури за часів влади совєтів» пропонує нарис історії української літератури радянського періоду. Багато з положень, накреслених критиком, набули надзвичайної актуальності вже після 1991 року. Історію української літератури від 1917 р. до 1950х рр. Юрій Шевельов поділяє на декілька періодів, які хронологічно збігаються 3 етапами боротьби українців за Незалежність: 1917 р. - початок 1920-х рр. - епоха визвольних змагань, коли з'являються представники українського національного модернізму й авангарду; початок 1920-х рр. - 1933 р. - епоха стрімкого розвитку української літератури за часів «коренізації» (хоча цей концепт Ю. Шевельов не вживає); 1933 р. - початок Другої світової війни, коли відбувається нищення української літератури; повоєнні роки, під час яких поновлення терору негативно впливає на ледь помітні й слабкі спроби українських радянських письменників віднайти свій оригінальний голос.

Деякі спостереження Ю. Шевельова вражають своєю влучністю, новизною й актуальністю. Так, говорячи про раннього Павла Тичину, критик зауважує, що поет представляє абсолютно оригінальний національний тип символізму, не схожий на західноєвропейський. Його ознакою $є$ закоріненість у національний грунт, матеріальність, яка народжує поетичні візії, що вирізняються «філософською глибиною, фундаментально музичним характером і оновленою єдністю 3 пісенною традицією» [17, с. 212]. Комбінація цих трьох чинників перетворює Павла Тичину «на найвидатнішого українського поета 1920-х рр.» [17, с. 212]. Українська національна революція 1917 року пробудила в П. Тичині чутливість «до внутрішньої музики світу, яка до певного часу спала в українській нації» [17, с. 212].

Високу оцінку в Юрія Шевельова дістає творчість неокласиків, завдяки яким «український світ вперше, в усіх смислах цього слова, набуває справжньої багатозначності, як це відбувається в поезії символістів західного світу» [17, с. 213]. Неокласики, разом із футуристами, сприяли остаточній європеїзації української літератури. Ю. Шевельов називає найяскравішого представника українського футуризму Михайля Семенка першим справжнім співцем урбанізму. Крім того, значення футуризму «...є надзвичайно велике, особливо коли йдеться про вдосконалення форми нової української поезї̈» [17, с. 213].

Період коренізації Юрій Шевельов називає часом загравання більшовиків із українською нацією, яке водночас відкриває можливість для найбільшого розквіту української літератури. Юрій Шевельов дає глибокі характеристики найяскравішим українським письменникам того часу Григорію Косинці, Володимиру Сосюрі, Юрію Яновському, Валеріану Підмогильному, Борису Антоненку-Давидовичу, Володимиру Гжицькому, Олексі Слісаренку, Майку Йогансену, Юрію Смоличу, Григорію Епіку, Івану Шевченку, Аркадію Любченку та іншим. Згадує критик есеїстику (Д. Донцов) боротьбу численних угрупувань. Проте найбільшу увагу Ю. Шевельова привертають дві постаті, які найповніше розкривають трагедію українських націонал-комуністів, спокушених квазімарксистською риторикою, що поширювалася в УРСР. Ідеться про Миколу Хвильового та Миколу Куліша.

Ідейно-естетична еволюція першого $\epsilon$ цілком показовою: розпочавши захопленням ідеалами комунізму, він завершує розчаруванням і гаслом «Геть від Москви!» та програмою «азіатського ренесансу». Доля Миколи Куліша склалася не менш драматично. Його місце, на думку Ю. Шевельова, в одному ряду з Георгом Кайзером, Юджином О'Нілом і Жаном Жироду. Непересічний талант драматурга дає М. Кулішу змогу піднести українську проблематику на рівень загальносвітового звучання. Невипадково критик порівнює п’єсу М. Куліша «Народний Малахій» із «Дон Кіхотом» Сервантеса. «Згадана драма написана у гротескному трагічному тоні, і вона є по суті новою версією "Дон Кіхота". Малахій нагадує постать лицаря 3 його безнадійною боротьбою з усіляким злом; водночас риси Санчо Панси представлені в образі Кума, його товариша, позбавленого ініціативи» [17, с. 218]. Комедія Миколи 
Куліша «Мина Мазайло» являє сатиру на радянську українізацію, а трагедія української революції найповніше розкрита у «Патетичній сонаті».

Ю. Шевельов підкреслює, що наслідки радянського терору для української духовності були фатальними: після 1933 року настав «для української літератури повний колапс разом із насильницькою русифікацією. Відтоді не побачив світ жоден важливий твір» $[17$, с. 223]. Ситуація не змінилася на краще і після війни. Нечисленні талановиті митці слова, що залишилися в СРСР, тікали або до ностальгійних спогадів про дитинство (О. Довженко), або у вигадані світи кохання (Олесь Гончар і Андрій Малишко). У будь-якому випадку українські автори вимушені були пристосовуватися до панівного дискурсу соцреалізму.

Спираючись на здійснений аналіз, Юрій Шевельов робить висновок, що радянський світогляд $є$ згубним для творчості, але, попри все, завершує свою розвідку критик на оптимістичній ноті: українська література продовжує існувати, $\mathrm{i}$ це $є$ справжнім дивом. Більше того, «українська література нас вчить, що українська нація ніколи не сприймала і на майбутнє не сприйматиме російського окупанта» $[17$, с. 224]. Щоправда, найкращі іiі представники зібралися на еміграції, за межами кордонів СРСР. Саме вони мають свободу й можливості, аби «виразити думки, мрії та справжні бажання нації» [17, с. 224].

\section{Висновки}

Духовні здобутки українських інтелектуалів еміграції, чиї праці були висвітлені у статті, слід визнати видатними. Картина літературного процесу, намальована ними, є доволі повною навіть за сучасними мірками. Крім того, вони зуміли запропонувати викладений зрозумілою західному читачеві метамовою наратив, який розкриває найкращі досягнення української літератури: іiі розквіт за часів бароко, творчість іiі найвідоміших класиків, таких як Іван Франко й Леся Українка, а також трагічну історію літературного процесу між 1917 - початком 1950-х рр.

Проте значення іспаномовних розвідок Д. Бучинського, П. Клюка, Д. Чижевського і Ю. Шевельова полягає не тільки в самому факті ознайомлення іспаномовної спільноти 3 іменами та явищами української літератури, а й у спробі прочитати останню у відповідному ключі. Сукупність їхніх герменевтичних практик можна резюмувати в таких рисах. 1) Вони дивляться на українську літературу як на відображення української ідентичності, що є феноменом національним i, водночас, європейським. Україна для них - не частина комуністичної імперії, не совєтизоване населення, яке живе в межах штучно сконструйованих кордонів УРСР, а невід'ємна частина західного світу. Д. Бучинський і П. Клюк реалізують цю риторику через зближення українських авторів 3 Іспанією, що зрозуміло, оскільки обидва інтелектуали жили в Мадриді. Підходи Д. Чижевського і Ю. Шевельова відрізняються значно ширшим європеїзмом. 2) Розвідки з української літератури, створені науковцями, $€$ епізодом тотальної війни 3 радянським літературним каноном, який вела і веде українська діаспора. У Д. Бучинського й П. Клюка це проявляється в запереченні потрактування творчості Івана Франка та Лесі Українки як революціонерів, натомість обидва дослідники наголошують на релігійних складниках світогляду цих українських письменників, а також на потребі вивчати доробок Наталени Королеви. Цю лінію якісно по-новому розвиває Д. Чижевський, який, представляючи добу бароко в українській літературі, підкреслює значення України як посередника в обміні ідей, у тому числі релігійних, між Заходом і Сходом. Окрема роль у «розрадяненні» українського літературного канону першої половини XX ст. належить Юрію Шевельову, який оголошує радянський світогляд смертельною загрозою літературній уяві. Він також пропонує альтернативний офіційному список імен ключових репрезентантів канону та подає приклади вільної від більшовицьких штампів інтерпретації творчості окремих найважливіших письменників. 
Вивчення іспаномовних літературознавчих розвідок дослідників діаспори має ще один вимір. Їхні наукові тексти інтегровані в культурну боротьбу української еміграції з СРСР. Проаналізовані у статті дослідницькі праці - крапля в безмежному океані інтелектуальної продукції, що з'являлася в різних частинах світу протягом десятиліть, але відображала ту саму мрію про Україну, вільну від радянського поневолення. Крізь цю краплю цікаво й корисно дивитися на практики сучасних українських літературознавців, які, часто того не усвідомлюючи, йдуть шляхами, торованими попередниками. Їхні імена та досі невідомі праці слід відкривати наново, аби відтворити уявлення про повноту й неперервність глобальної української літературознавчої традиції, яка продовжує підживлювати своїми ідеями методологію сучасних вітчизняних і закордонних дослідників красного письменства.

\section{СПИСОК ВИКОРИСТАНИХ ДЖЕРЕЛ}

1. Anonymous (б.а.). Філадельфійський осередок наукового товариства ім. Шевченка Америки (США): історія, сучасність [Електронний ресурс] / Anonymous // Наукове товариство ім. Шевченка: он-лайн журнал товариства. - 2011. - 25.04. Режим доступу: https://ntsh.org/content/filadelfiyskiy-oseredok-na-ukovogotovaristva-im-shevchenka-ameriki-ssha-istoriya-suchasnist (дата звернення: 31.05.2020).

2. Бучинський Д. Християнсько-філософська думка Тараса Шевченка / Дмитро Бучинський. - Мадрид-Лондон : Союз Українців у Великій Британії, 1962. - 256 с.

3. Бучинський Д. Юрій Клен в житті і творчості / Дмитро Бучинський. - Клівленд : Об’єднання жінок Організації Оборони Чотирьох Свобід України, 1992. - 44 с.

4. Доценко Р. I. Бучинський Дмитро Григорович [Електронний ресурс]/ P. I. Доценко // Енциклопедія сучасної України. - Режим доступу: http://esu.com.ua/search_articles.php?id=38388 (дата звернення: 31.05.2020).

5. Литвинець В. М. Клюк Петро [Електронний ресурс] / В. М. Литвинець // Енциклопедія сучасної України. - Режим доступу: http://esu.com.ua/search_articles.php?id=8614 (дата звернення : 31.05.2020).

6. Ряст О. (Симон Петлюра). Сучасна українська еміграція та ії завдання / О. Ряст (Симон Петлюра). - Щипіорно : Друкарня т. Щипіорно, 1923. - 89 с.

7. Романюк Т. Бучинський Дмитро [Електронний ресурс]/ Тарас Романюк// Енциклопедія Наукового товариства імені Шевченка. - Режим доступу: http://encyclopedia.com.ua/search_articles.php?id=475 (дата звернення : 31.05 .2020 ).

8. Яримович В., Білик О., Волинський М. Нарис історії Української Студентської Громади та Українських Поселень в Еспанії 1946-1996 / Володимир Яримович, Олександер Білик, Микола Волинський. - Філадельфія-Мадрид: Накладом групи колишніх українських студентів в Еспанії, 1997. - 196 с.

9. Buchínskiy D. Ivan Frankó y literatura española / Dmitró Buchínskiy // La revista de literatura. - 1953. - Núm. 1. - P. 55-77.

10. Buchínskiy D. Iván Frankó / Dmitró Buchínskiy // Poesía española. - 1956. Núm. 56. - P. 26.

11. Eiroa M. La información sobre Hungría en la España de posguerra (a propósito de algunas sugerencias del profesor Anderle)/ M. Eiroa // Encrucijadas. Estudios sobre la historia de las relaciones húngaro-españolas [Ed. Z. Csikós]. - Huelva : Universidad de Huelva, 2013. - P. 97-109.

12. Frankó I. (1956) «Cristo y la Cruz», «Conquistadores»/ Iván Frankó // Poesía española. - 1956. - Núm. 56. - P. 26-28.

13. González M. R. Morillo, Santiago Treviño [Electronic resource] / Manuel Revuelta González. - Access mode: http://dbe.rah.es/biografias/20697/santiago-morillo-trevino (accessed : 31.05.2020).

14. Kluk P. La temática española en la poesía ucraniana, director María del Pilar Palomo : tesis, disertación / Petro Kluk. - Madrid / Universidad Complutense de Madrid, Facultad de Filosofía y Letras, 1971. - 410 p. 
15. Lesia Ukrainka. Dueño de piedra / Lesia Ukrainka // Lesia Ukrainka in translations: English, German, Spanish, French, Croatian, Portuguese, Italian. - Philadelphia: The Commemorative Committee to Honor Lesia Ukrainka, 1988. - P. 195-252.

16. Pronkévych O., Shestopal O. Ukrainian Students in Spain after World War II / Oleksandr Pronkévych, Olga Shestopal // Kyiv Mohyla Humanities Journal. - 2018. № 5. - P. 117-132.

17. Shevelov G. Las tendencias en la literatura ucraniana bajo el dominio de los soviets / George Shevelov // Oriente Europeo. - 1957. - № 26. - P. 211-224.

18. Stelmajiv Y. La emigración ucraniana en el mundo libre / Yaroslav Stelmajiv // Oriente Europeo.- 1957. - № 26. - P. 243-250.

19. Tschizewskij D. El barroco en la literatura ucraniana / Dmytro Tschizewskij // Oriente Europeo. - 1957. - № 26. - P. 181-193.

\section{REFERENCES}

1. Anonymous (2011) Filadelphiys'kyy oseredok naukovoho tovarystva imeni Shevchenka Ameryky (SShA): istoriya, suchasnist' [Philadelphian center at the formation society named after Shevchenko of America (USA): history, modern (in English)] [Electronic resource] / Anonymous // Naukove tovarystvo im. Shevchenka: on-line zhurnal tovarystva. - 25.04. - Access mode:

https://ntsh.org/content/filadelfiyskiy-oseredok-na-ukovogo-tovaristva-im-shevchenkaameriki-ssha-istoriya-suchasnist (accessed: 31.05.2020).

2. Buchynskiy D. (1962) Chrystians'ko-filosofs'ka dumka Tarasa Shevchenka [Christian and Philosophical Thought of Taras Shevchenko (in English)] / Dmytro Buchynskiy. Madird-London: Soiuz Ukrainstiv u Velykiy Brytaniyi, 1962. - $256 \mathrm{~s}$.

3. Buchynskiy D. (1992) Yyriy Klen v zhytti i tvorchosti [Yuriy Klen in Life and Works (in English)] / Dmytro Buchynskiy. - Cleveland: Obiednannia zhinok Organizatsii Chotyriokh Svobid Ukrainy. - 44 s.

4. Dotsenko R. I. Bychynskiy Dmytro Hryhorovych [Electronic resource]/ R. I. Dotsenko // Entsyklopedia suchasnoyi Ukrayiny. - Access mode : http://esu.com.ua/search_articles.php?id=38388 (accessed: 31.05 .2020 ).

5. Lytvynets' V. M. Kliuk Petro [Electronic resource] / V. M. Lytvynets' // Entsyklopedia suchasnoyi Ukrayiny. - Access mode : http://esu.com.ua/search_articles.php?id=8614 (accessed: 31.05.2020).

6. Riast O. (Symon Petliura) (1923) Suchasna ukrayins'ka emigratsiya ta yiyi zavdannia [Contemporary Ukrainian Emigration and its Tasks (in English)] / O. Riast (Symon Petliura). - Tsypiorno: Drukarnia t. Tsypiorno. $-89 \mathrm{~s}$.

7. Romaniuk T. Buchynskiy Dmytro [Electronic resource]/ Taras Romaniuk// Entsyklopedia Naukovoho tovarystva im. Shevchenka. - Access mode : www.ukrnauka.com (accessed: 31.05.2020).

8. Yarymovych V., Bilyk O., Volynskiy M. (1997) Narys istoriyi Ukrayins'koyi students'koyi Hromady ta Ukrayins'kykh poselen' v Espaniyi 1946-1996 [Outline of History of the Ukrainian Student Community and Ukrainian Settlements in Spain 19461996 (in English)] / Volodymyr Yarymovych, Oleksander Bilyk, Mykola Volynskiy. Philadelphia-Madrid: Nakladom hrupy kolyshnikh ukrainskykh studentiv v Espanii, 1997. - $196 \mathrm{~s}$.

9. Buchínskiy D. (1953) Ivan Frankó y literatura española / Dmitró Buchínskiy // La revista de literatura. - Núm. 1. - P. 55-77.

10. Buchínskiy D. (1956) Iván Frankó / Dmitró Buchínskiy // Poesía española. Núm. 56. - P. 26.

11. Eiroa M. (2013) La información sobre Hungría en la España de posguerra (a propósito de algunas sugerencias del profesor Anderle) / M. Eiroa // Encrucijadas. Estudios sobre la historia de las relaciones húngaro-españolas [Ed. Z. Csikós]. - Huelva : Universidad de Huelva. - P. 97-109. 
12. Frankó I. (1956) «Cristo y la Cruz», «Conquistadores»/ Iván Frankó// Poesía española. - Núm. 56. - P. 26-28.

13. González M. R. Morillo, Santiago Treviño [Electronic resource] / Manuel Revuelta González. - Access mode: http://dbe.rah.es/biografias/20697/santiago-morillo-trevino (accessed : 31.05.2020)

14. Kluk P. (1971) La temática española en la poesía ucraniana, director María del Pilar Palomo : tesis, disertación / Petro Kluk. - Madrid / Universidad Complutense de Madrid, Facultad de Filosofía y Letras. -410 p.

15. Lesia Ukrainka (1988) Dueño de piedra / Lesia Ukrainka// Lesia Ukrainka in translations: English, German, Spanish, French, Croatian, Portuguese, Italian. Philadelphia: The Commemorative Committee to Honor Lesia Ukrainka. - P. 195-252.

16. Pronkévych O., Shestopal O. (2018) Ukrainian Students in Spain after World War II / Oleksandr Pronkévych, Olga Shestopal // Kyiv Mohyla Humanities Journal. - № 5. P. 117-132.

17. Shevelov G. (1957) Las tendencias en la literatura ucraniana bajo el dominio de los soviets / George Shevelov // Oriente Europeo. - № 26. - P. 211-224.

18. Stelmajiv Y. (1957) La emigración ucraniana en el mundo libre / Yaroslav Stelmajiv // Oriente Europeo. - № 26. - P. 243-250.

19. Tschizewskij D. (1957) El barroco en la literatura ucraniana / Dmytro Tschizewskij // Oriente Europeo. - № 26. - P. 181-193.

Received: 25 March, 2020 